Check for updates

Cite this: RSC Adv., 2017, 7, 21136

Received 10th January 2017

Accepted 7th April 2017

DOI: $10.1039 / c 7 r a 00384 f$

rsc.li/rsc-advances

\section{L-aspartate oxidase magnetic nanoparticles: synthesis, characterization and L-aspartate bioconversion}

\author{
Ilaria Armenia, (D) a Riccardo Balzaretti, (D) a Cristina Pirrone, ${ }^{a}$ Chiara Allegretti, ${ }^{\text {b }}$ \\ Paola D'Arrigo, ${ }^{\text {bcd }}$ Mattia Valentino, ${ }^{\text {cd }}$ Rosalba Gornati, ${ }^{\text {ac }}$ Giovanni Bernardini iD *ac \\ and Loredano Pollegioni ${ }^{\text {ac }}$
}

The FAD-containing enzyme L-aspartate oxidase (LASPO) catalyzes the stereospecific oxidative deamination of L-aspartate and L-asparagine functioning under both aerobic and anaerobic conditions. LASPO possesses distinctive features that make it attractive for biotechnological applications. In particular, it can be used for the production of D-aspartate from a racemic mixture of D,L-aspartate, a molecule employed in the pharmaceutical industry, for parenteral nutrition, as a food additive and in sweetener manufacture. Since the industrial application of LASPO is hampered by the high cost per enzymatic unit, several attempts have been performed to improve its reusability, such as LASPO immobilization on various matrices. In this context, magnetic nanoparticles (NPs) have recently become available for the immobilization of enzymes. In this work, we have covalently immobilized LASPO from the thermophilic archaea Sulfolobus tokodaii on iron oxide NPs using 1-ethyl-3-(3-dimethylaminopropyl) carbodiimide and hydroxysuccinimide as cross-linking agents. The NP-LASPO system showed a better stability than the free enzyme, was reused five times reaching full L-aspartate conversion and yielded a productivity ( $>3 \mu \mathrm{mol}$ per $\mathrm{h}$ per unit) similar to that obtained with the free enzyme or with the enzyme immobilized on classical chromatographic supports. The NP-LASPO system can be easily recovered after each cycle. These results indicate that the prepared NP-LASPO system has promising industrial applications.

\section{Introduction}

The FAD-containing enzyme L-aspartate oxidase (LASPO, EC 1.4.3.16) catalyzes the stereospecific oxidative deamination of $\mathrm{L}^{-}$ aspartate and L-asparagine to the corresponding imino acid and, following spontaneous hydrolysis, an $\alpha$-keto acid (i.e. oxaloacetate from L-aspartate) along with the production of ammonia and hydrogen peroxide. The ability of LASPO to use both $\mathrm{O}_{2}$ and fumarate in reoxidation of the reduced flavin cofactor enables it to function under both aerobic and anaerobic conditions. ${ }^{1}$ This agrees with the physiological role of the enzyme in prokaryotes, which is to catalyze the first step of NAD+ biosynthesis. Notably, LASPO distinguishes from the family members of the amino acid oxidases, most closely resembling the succinate dehydrogenase/fumarate reductase

${ }^{a}$ Dipartimento di Biotecnologie e Scienze della Vita, Università degli Studi dell'Insubria, Via J.H. Dunant 3, 21100 Varese, Italy. E-mail: giovanni.bernardini@ uninsubria.it

${ }^{b}$ Dipartimento di Chimica, Materiali e Ingegneria Chimica "Giulio Natta”, Politecnico di Milano, Piazza Leonardo da Vinci 32, 20133 Milano, Italy

'The Protein Factory, Politecnico di Milano, ICRM CNR Milano, Università degli Studi dell'Insubria, Via Mancinelli 7, 20131 Milano, Italy

${ }^{d}$ CNR - Istituto di Chimica del Riconoscimento Molecolare (ICRM), Via Mancinelli 7, 20131 Milano, Italy family of flavoproteins; indeed, LASPO is not evolutionarily related to the L-amino acid oxidase members. ${ }^{2}$

In past years, we focused on LASPO from the thermophilic archaea Sulfolobus tokodaii (StLASPO), a monomeric protein (comprising 472 residues, $52 \mathrm{kDa}$ ) which folds into three distinct domains: a FAD-binding domain, a capping domain, and a helical domain. ${ }^{3}$ StLASPO is produced as a recombinant protein in $E$. coli, while classical L-amino acid oxidases with a broad substrate specificity are not. It is produced as active holoenzyme (the flavin cofactor is tightly, but non-covalently, bound to the protein moiety) reaching up to $9 \%$ of the total proteins in the crude extract and $13.5 \mathrm{mg} \mathrm{L}^{-1}$ in the fermentation broth.,

We focused on this enzyme since it possesses distinctive features that make it attractive for biotechnological applications. ${ }^{5}$ Indeed, LASPO possesses high thermal stability (it is fully stable up to $80{ }^{\circ} \mathrm{C}$ ), high temperature optimum, stable activity in a broad range of $\mathrm{pH}$ (7.0-10.0), weak inhibition by the product and by the D-isomer of aspartate, and a quite low $\mathrm{Km}$ for dioxygen $(0.3 \mathrm{mM})$. These properties make StLASPO a potential useful novel tool in biocatalysis where it can be used in applications resembling those developed for D-amino acid oxidase of opposite enantioselectivity. ${ }^{6}$ In particular, it can be used for the production of D-aspartate, a molecule 
employed in the pharmaceutical industry, for parenteral nutrition, as food additive and in sweetener manufacturing. ${ }^{5}$ On this side, when applied in the free form, the resolution of a $50 \mathrm{mM}$ racemic mixture of $\mathrm{D}, \mathrm{L}$-aspartate was obtained in one day using 9 U of StLASPO (final e.e. $>99.5 \%$ ). ${ }^{4}$

To facilitate industrial applications by improving reusability and, hence, by reducing the costs, StLASPO was immobilized on various matrices. The best results in terms of immobilization yield and volumetric activity have been obtained through the free amino groups of the enzyme by using the supports Relizyme ${ }^{\mathrm{TM}}$ HA403/S R and SEPABEADS® EC-EP/S or when prepared as crosslinked enzyme aggregates. The Relizyme-StLASPO immobilized preparation was reused for three cycles keeping full oxidation of $\mathrm{L}$-aspartate, in $\leq 2$ hours starting from a $50 \mathrm{mM}$ racemic mixture: in a semi-preparative scale reaction, $66 \mathrm{mg}$ of $\mathrm{D}$-aspartate per day were produced using $20 \mathrm{U}$ of StLASPO. ${ }^{7}$

With the development of nanotechnology, magnetic nanoparticles (NPs) have become available for the immobilization of enzymes. Magnetic NPs, when small enough, show superparamagnetic behaviors with a fast response to applied magnetic fields and with negligible residual magnetism and coercitivity. This means that these NPs can be magnetized with an external magnetic field and immediately redispersed once the magnet is removed. ${ }^{8}$ We have recently functionalized iron oxide NPs with Damino acid oxidase for therapeutic purposes and obtained a magnetic nano-enzymatic system capable of producing, in presence of its substrate, reactive oxygen species., ${ }^{\mathbf{9}, 10}$ This system, which possesses relatively low toxicity, ${ }^{11}$ might be driven to the target area by an external magnetic field. Magnetic nano-enzymes can be used in several other fields such as biosensors for environmental pollutants and clinical sensors for biomolecules. A caveat, when using NPs, is always a concern about their safety. ${ }^{12}$ Iron NPs, however, have been shown to exert a relatively low toxicity. ${ }^{11,13}$

The application of StLASPO has few limitations due to the high cost per enzymatic unit and inability of separation. Among the approaches useful to improve the enzyme stability, the immobilization has proven particularly valuable. On this side, significant improvement has been made by enzyme immobilization onto magnetic nanocarriers. They can be advantageously employed as industrial catalysts since they have high surface area, large surface-to-volume ratio, lower hindrance, allow to regulate the orientation of the enzyme on the support and to easily remove the enzyme by applying a magnetic field. ${ }^{\mathbf{1 4 , 1 5}}$

To generate an immobilized StLASPO system differing in mechanical, physical and diffusional properties, we focused on the setup of magnetic NP-LASPO that can be easily recovered from the reaction mixture and, potentially, applied under different practical conditions as compared to classical resinimmobilized enzyme preparations. Following the optimization of the immobilization procedure, the NP-LASPO system was characterized for the main physical-chemical properties and then used to convert L-aspartate into oxaloacetate and ammonia. The flavoenzyme system can be reused for 4 cycles with no loss of activity. This result paves the way to the set-up of innovative biocatalytic processes.

\section{Experimental}

\section{Chemicals}

Iron oxide nanoparticles $\left(\mathrm{Fe}_{3} \mathrm{O}_{4} \mathrm{NPs},<50 \mathrm{~nm}\right),(3$-aminopropyl) triethoxylsilane (APTES), 1-ethyl-3-(3-dimethylaminopropyl) carbodiimide (EDC), hydroxysuccinimide (NHS), 4-amino antipyrine (4-AAP), L-aspartic acid, glycine, phenol: all purchased from Sigma Aldrich (Milan, Italy). Horseradish peroxidase (POD) was purchased from Roche (Milan, Italy).

\section{Enzyme preparation}

StLASPO was overexpressed in $E$. coli cells and was purified to $>95 \%$ purity by the procedure described by (ref. 4 ). The purified StLASPO was stored in $20 \mathrm{mM}$ Tris-HCl buffer at $\mathrm{pH} 7.5$ and $10 \%$ (v/v) glycerol; its specific activity was $\sim 0.43 \mathrm{U} \mathrm{mg}^{-1}$ of protein on L-aspartate as substrate.

\section{Functionalization of NPs with APTES}

$\mathrm{Fe}_{3} \mathrm{O}_{4} \mathrm{NPs}$ were functionalized according to the protocol of (ref. 16). Briefly, $5 \mathrm{~mL}$ of $2 \%(\mathrm{v} / \mathrm{v})$ APTES in milliQ water were added to a suspension of $\mathrm{Fe}_{3} \mathrm{O}_{4} \mathrm{NPs}(150 \mathrm{mg})$ and the reaction was maintained under mechanical stirring for $5 \mathrm{~h}$ at $50{ }^{\circ} \mathrm{C}$. Aminofunctionalized nanoparticles (NP-APTES) were then separated from unbound APTES by a commercial parallelepiped neodymium magnet (Webcraft GmbH, Uster, Switzerland; Ni$\mathrm{Cu}-\mathrm{Ni}$ plated; magnetization: N45; size: $30 \times 30 \times 15 \mathrm{~mm}$ ), washed several times with water and anhydrified with ethanol overnight. NPs were suspended in water, isolated and dried at $50{ }^{\circ} \mathrm{C}$ overnight.

\section{Synthesis of NP-LASPO}

$16 \mathrm{mg}$ of NP-APTES were sonicated in $5 \mathrm{mM}$ sodium pyrophosphate buffer at $\mathrm{pH}$ 8.5. Then a solution of EDC $(65 \mathrm{mM}$ final concentration) and NHS (13 mM final concentration) were added under sonication in a final volume of $2 \mathrm{~mL}$. Finally, 200 $\mu \mathrm{g}$ of pure StLASPO were added and the reaction was carried out for $2 \mathrm{~h}$ at room temperature on a rotating plate tube stirrer. Subsequently, StLASPO conjugated NPs (NP-LASPO) were collected by a magnet and washed twice with $2 \mathrm{~mL}$ of $5 \mathrm{mM}$ sodium pyrophosphate buffer, $\mathrm{pH}$ 8.5. The resulting conjugated enzyme was stored at $4{ }^{\circ} \mathrm{C}$ until use.

\section{Characterization}

Shape, size, and size distribution of $\mathrm{Fe}_{3} \mathrm{O}_{4} \mathrm{NPs}$, NP-APTES and NP-LASPO were investigated by transmission electron microscopy (TEM) with JEOL 1010 electron microscope (JEOL, Tokyo, Japan). Samples were dispersed in milliQ water on carbon coated copper grids and dried at room temperature.

\section{Activity assay}

Activity of StLASPO and NP-LASPO was assayed by measuring the initial rate of production of hydrogen peroxide with a coupled peroxidase/dye assay at different temperatures. The standard assay mixture contained $10 \mathrm{mM}$ L-aspartate in $50 \mathrm{mM}$ sodium pyrophosphate buffer, $\mathrm{pH} \quad 8.5, \quad 1.5 \quad \mathrm{mM} \quad 4$ - 
aminoantipyrine, $2 \mathrm{mM}$ phenol, $20 \mu \mathrm{M}$ FAD, $2.5 \mathrm{U}$ of peroxidase, and $30 \mu \mathrm{g}$ of StLASPO in a total volume of $1 \mathrm{~mL}$. The colored product generated by peroxidase from $\mathrm{H}_{2} \mathrm{O}_{2}$ and 4aminoantipyrine was detected spectrophotometrically at $505 \mathrm{~nm}\left(\varepsilon=6.58 \mathrm{mM}^{-1} \mathrm{~cm}^{-1}\right) .{ }^{4}$ One unit (U) is defined as the amount of enzyme that catalyzes the degradation of $1 \mu \mathrm{mol}$ of $\mathrm{L}^{-}$ aspartate per min.

\section{Oxidation of L-aspartate by conjugated StLASPO}

The oxidation of $\mathrm{L}_{\text {-aspartate }}$ was carried out by adding $50 \mu \mathrm{L}$ of $50 \mathrm{mM}$ amino acid solution (in water, prepared and adjusted to the desired pH with $0.5 \mathrm{M} \mathrm{NaOH}$ ) and $150 \mu \mathrm{L}$ of water to the immobilized enzyme ( $4 \mathrm{mg}$ of support corresponding to $\approx$ $0.104 \mathrm{U}$ of StLASPO). All reactions were performed at $70{ }^{\circ} \mathrm{C}$, in a thermomixer set to $600 \mathrm{rpm}$ and at different $\mathrm{pH}$ values (in the 8-11 range). The dependence of the residual activity after 60 min of incubation on $\mathrm{pH}$ was fitted using an equation for a single ionization according to Harris and Colleagues. ${ }^{17}$

To investigate the stability of NP-LASPO on temperature, the same reaction was performed at $\mathrm{pH} 10.0$ in the $25-80{ }^{\circ} \mathrm{C}$ range: samples were collected at different time intervals for measurements. For the recycling of the NP-LASPO, at the end of each cycle NPs were collected with a magnet, washed several times and stored in the storage buffer. In all cases, the oxidation of $\mathrm{L}^{-}$ aspartate was assayed by HPLC separation (see below).

\section{HPLC analysis}

The OPA-NAc reagent was prepared by dissolving $4 \mathrm{mg}$ of orthophthalaldehyde (OPA) in $300 \mu \mathrm{L}$ of methanol, followed by the addition of $250 \mu \mathrm{L}$ of $0.4 \mathrm{M}$ borate buffer at $\mathrm{pH} 9.4 .^{18}$ To this mixture, $15 \mu \mathrm{L}$ of $1 \mathrm{M} \mathrm{N}$-acetylcysteine (NAc) in $1 \mathrm{M} \mathrm{NaOH}$ were added, and then the solution was diluted with $435 \mu \mathrm{L}$ of distilled water. At fixed intervals, $10 \mu \mathrm{L}$ aliquots were withdrawn from the reaction mixture and diluted with $40 \mu \mathrm{L}$ of distilled water: $10 \mu \mathrm{L}$ of this solution were derivatized with $25 \mu \mathrm{L}$ of OPA-NAc reagent, diluted with $25 \mu \mathrm{L}$ of HPLC eluent and analyzed by HPLC chromatography on a symmetry C8 column $(100 \AA$, $5 \mu \mathrm{m}, 3.9 \mathrm{~mm} \times$ $150 \mathrm{~mm}$; Waters, Milano, Italy). Eluent: $50 \mathrm{mM}$ sodium acetate

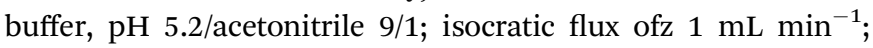
absorbance detection at $340 \mathrm{~nm} .^{7}$ The separation allows to easily distinguish and quantify L-aspartate from glycine (used as internal standard) and thus to calculate the bioconversion yield; $R_{\mathrm{t}}$ (glycine): $10.5 \mathrm{~min}, R_{\mathrm{t}}$ (L-aspartate) $4.5 \mathrm{~min}$.

\section{Results and discussion}

\section{Optimization of StLASPO conjugation}

StLASPO was conjugated to NP-APTES using EDC/NHS reaction by a two-step process. The scheme of NP activation and enzyme conjugation is illustrated in Fig. 1. With this two steps reaction, different conjugations can occur (Fig. 1): an enzyme molecule could interact with just one NP-APTES (product A), an enzyme molecule could react with amino groups of different NPs (product B) and an enzyme molecule could react with more than one amino groups of the same NP (product $\mathrm{C}$ ). ${ }^{\mathbf{1 9 , 2 0}}$

In order to identify the best conditions for the enzyme conjugation, several factors have been taken into consideration: EDC : NHS ratio, NPs: enzyme ratio, the presence of FAD (the enzyme cofactor), substrate or product (Table 1). At each condition, the immobilization yield and the enzyme activity bound to NP-APTES were determined.

The concentrations of EDC and NHS have to be carefully chosen to yield complete activation of the binding sites and, at the

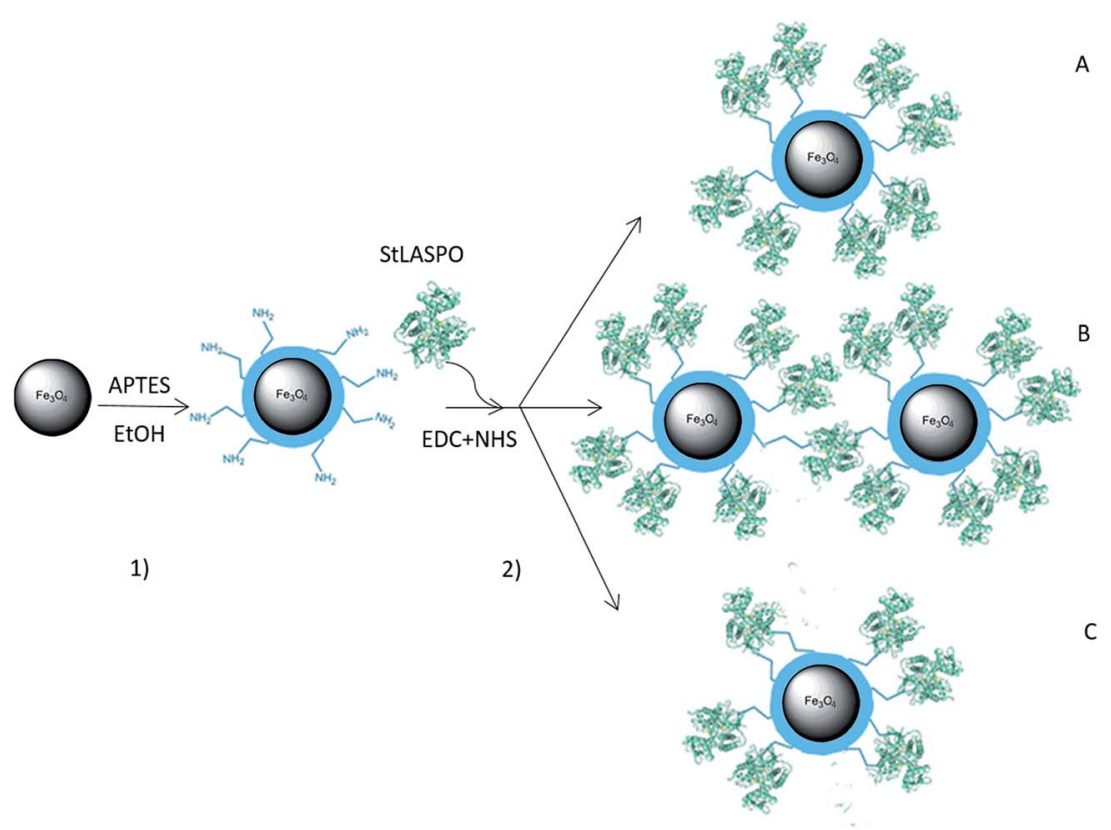

Fig. 1 Synthetic route for StLASPO conjugation on $\mathrm{Fe}_{3} \mathrm{O}_{4} \mathrm{NPs}$ (not in scale). The protein structure corresponds to PDB code 2E5V. (1) Functionalization of $\mathrm{Fe}_{3} \mathrm{O}_{4} \mathrm{NPS}$ with APTES; (2) conjugation of StLASPO through covalent linkage via EDC/NHS. The enzyme can interact with just one NP-APTES (product A) or with amino groups of different NPs (product B) or with more than one amino groups of the same NP (product C). 
Table 1 Conditions for StLASPO conjugation to $\mathrm{Fe}_{3} \mathrm{O}_{4} \mathrm{NPs}$. StLASPO was used at concentration of $100 \mu \mathrm{g} \mathrm{mL}{ }^{-1}$; $\mathrm{EDC}$ : NHS molar ratios are reported in the second column ${ }^{a, b, c}$

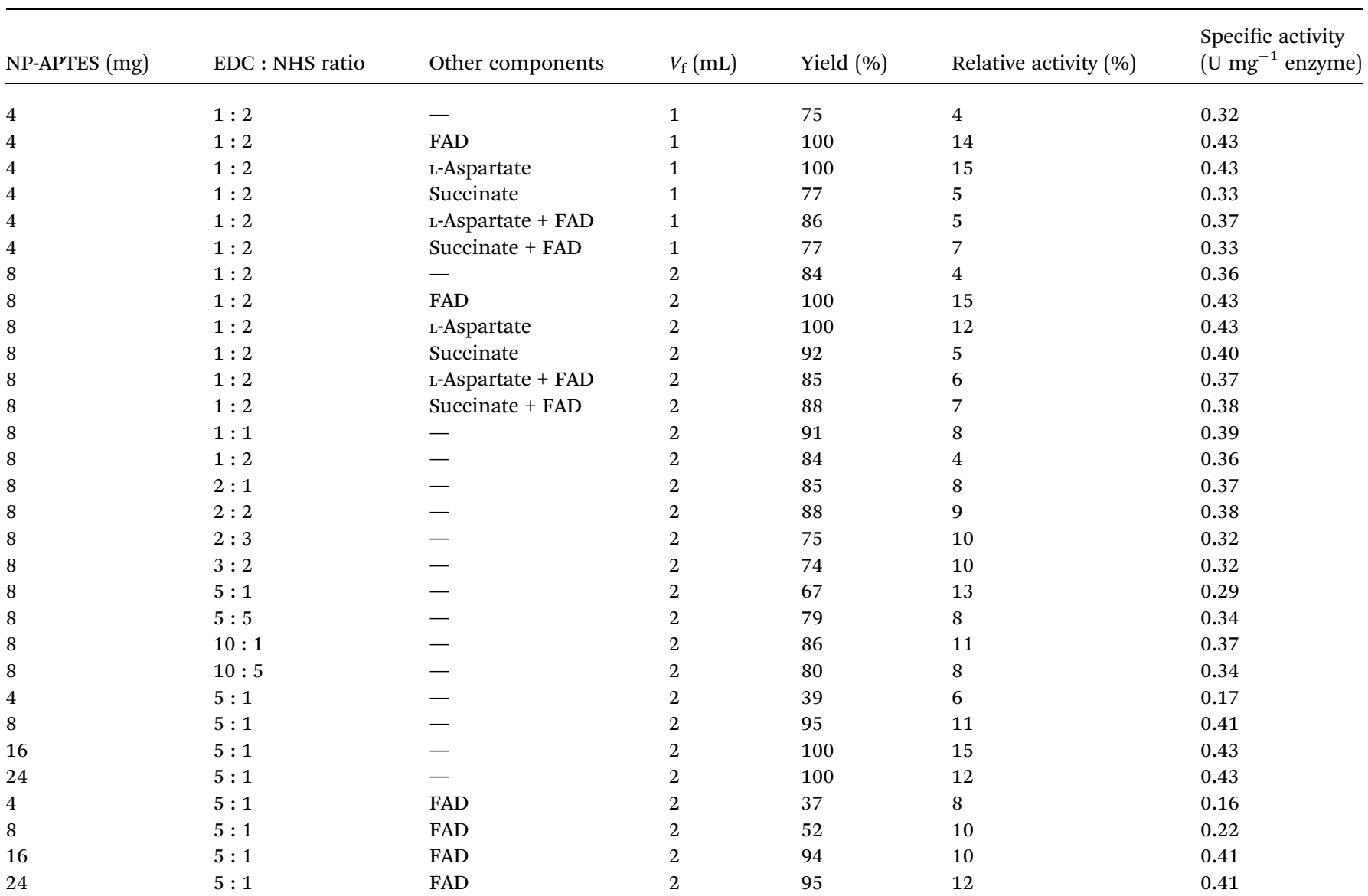

${ }^{a}$ Reaction conditions: during StLASPO conjugation, $100 \mu \mathrm{M}$ FAD $1 \mathrm{mM}$ L-aspartate and/or $200 \mu \mathrm{M}$ succinate were added. ${ }^{b}$ Yield has been calculated from units present in the supernatant of the immobilization reaction relatively to the total units. ${ }^{c}$ Relative activity is reported as the ratio between the activity assayed for the NP-LASPO and the activity of the free enzyme.

same time, to prevent formation of unwanted surface by-products ${ }^{21}$ such as the $\mathrm{N}$ acetyl-substituted, derivative of the unstable intermediate of the EDC. Indeed, during the reaction in aqueous solution, $\mathrm{O}$-acetyl urea is formed and, if it fails to react with an amine, undergoes to hydrolysis. ${ }^{22}$ Furthermore, an excess of EDC may promote unwanted polymerization due to the abundance of both amines and carboxylates on protein molecules leading to a protein-to-protein cross-linking. ${ }^{20}$ There is also the risk that the NHS esters formed on the protein molecule may then couple to other protein molecules to give poorly defined polymers. ${ }^{23}$ As a general rule, the amount of StLASPO activity bound to the NPS increases at higher EDC : NHS ratios (reaching the maximum at a $5: 1$ value) and using increasing NP-APTES amounts.

The presence of FAD significantly increases both the units and the amount of the enzyme bound to NPs at low $(1: 2)$ EDC : NHS ratio. The positive effect of the flavin cofactor is less evident at higher EDC : NHS ratios (e.g., its presence resulted in a 1.3 fold increase in immobilized StLASPO activity at $5: 1$ EDC : NHS ratio and using $4 \mathrm{mg}$ of NP-APTES).

Similarly, the substrate L-aspartate also positively affects StLASPO immobilization in an active form, while the product analogue succinate does not. Notably, the use of the FAD and Laspartate together results in an enzyme conformational change that does not favor its immobilization.

Under the best experimental conditions - i.e. $16 \mathrm{mg}$ of NPAPTES in $5 \mathrm{mM}$ sodium pyrophosphate buffer, pH 8.5, $65 \mathrm{mM}$ EDC, $13 \mathrm{mM}$ NHS, $200 \mu \mathrm{g}$ of enzyme, final volume $2 \mathrm{~mL}$ - the amount of enzyme bound to NPs was approximately $100 \%$, with an enzymatic activity of $0.026 \mathrm{U} \mathrm{mg}^{-1}$ of NPs and a relative activity of $15 \%$ (Table 1). Relative activity values strongly depend on the enzyme and the conditions used. Indeed, relative activities ranging from less than $10 \%$ to more than $80 \%$ in relation to the diameter of the NP, its functionalization and the immobilized enzyme are reported in the literature. ${ }^{24-26}$ Furthermore, the reduction of relative activity might be due also to the chemistry of EDC/NHS conjugation that determines non-specific bindings between NP-APTES and the enzyme molecules. Actually, when the covalent bonds are formed close to the active site, an activity loss due to conformational changes can occur. ${ }^{27,28}$ Under the best conjugation conditions, the specific activity of the immobilized enzyme for the L-aspartate is $0.43 \mathrm{U} \mathrm{mg}$ of enzyme (Table 1), comparable to the specific activity of the free enzyme. As for the 
A
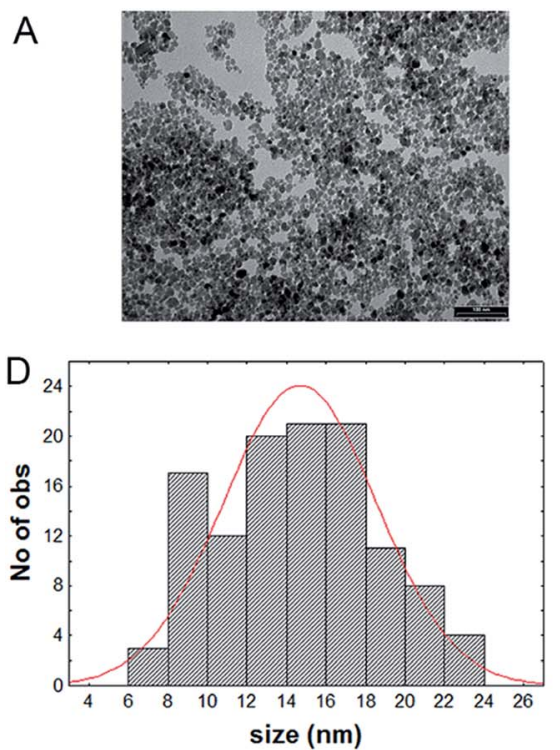

B
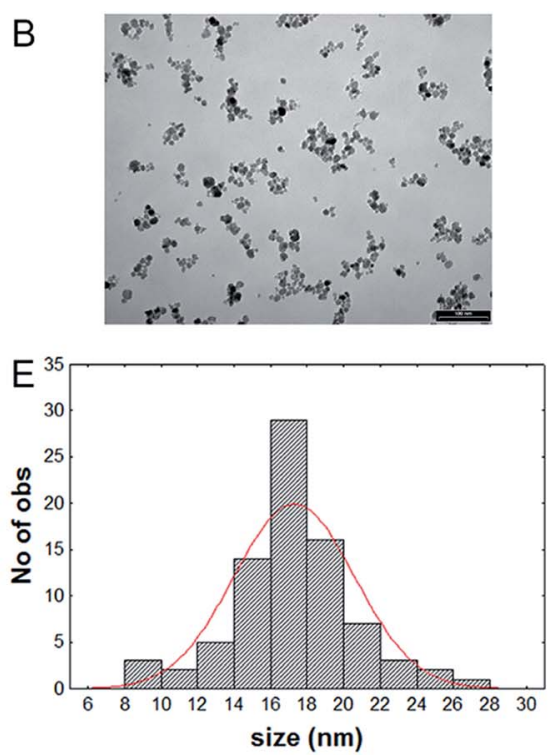

C
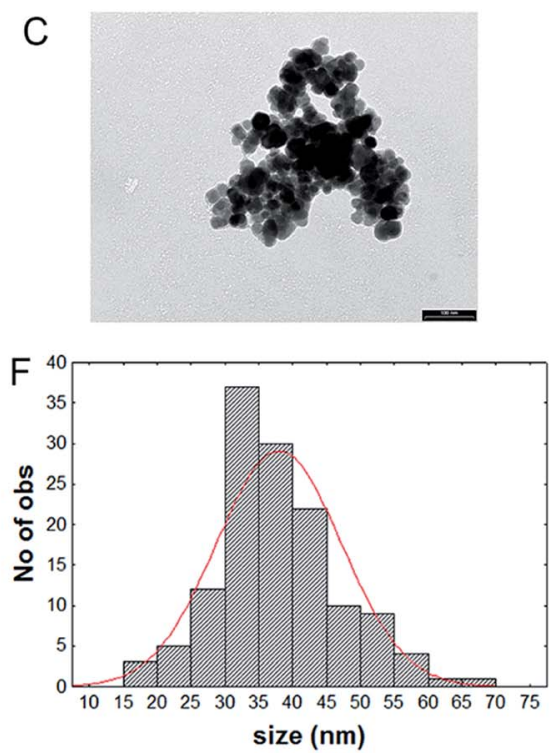

Fig. 2 Transmission electron microscopy (TEM) and size distribution of $\mathrm{Fe}_{3} \mathrm{O}_{4} \mathrm{NPs}$ (A and D), NP-APTES (B and E), NP-LASPO (C and F). Bars in panel A-C indicate $100 \mathrm{~nm}$.

relative activity, specific activity depends on the enzyme and the conditions of the immobilization process. Therefore, the conjugation can affect also the specific activity. ${ }^{29-31}$

\section{NP-LASPO properties}

TEM images indicate that $\mathrm{Fe}_{3} \mathrm{O}_{4} \mathrm{NPs}$ and NP-APTES show a spherical shape, with an average diameter of $14.6 \pm 3.8 \mathrm{~nm}$ and $17.2 \pm 3.2 \mathrm{~nm}$ respectively, and with a good dispersion (Fig. 2A and B). On the other end, NP-LASPO show the tendency to aggregate and a more irregular shape, with an average diameter of $38.0 \pm 9.8 \mathrm{~nm}$ (Fig. 2C). This slight tendency to aggregation can be explained by the possibility that several carboxylic groups located on the enzyme surface may react with the amine groups of different NP-APTES causing a cross-linking leading to aggregation..$^{32}$ However, this phenomenon is not massive since no NPs precipitation was apparent.

The immobilized NP-LASPO maintains the absolute stereoselectivity of the free enzyme, i.e., the $\mathrm{D}$-isomer of $\mathrm{L}$-aspartate

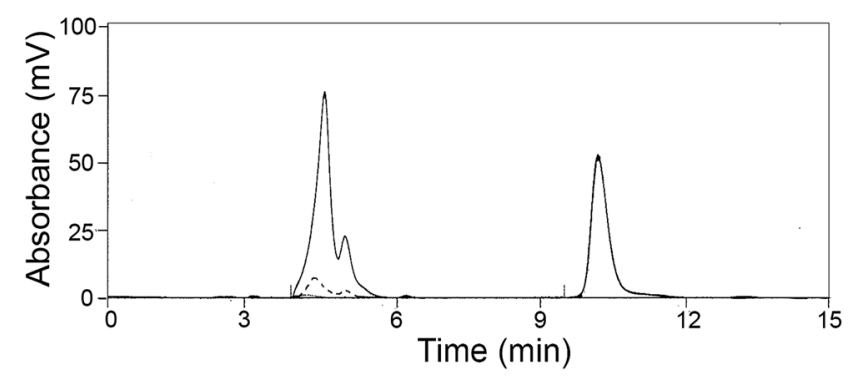

Fig. 3 HPLC separation of L-Asp solution during oxidation by NPLASPO. Conditions: $50 \mu \mathrm{L}$ of $50 \mathrm{mM}$ L-aspartate in milliQ water, $\mathrm{pH}$ 9.0, added of $8 \mathrm{mg}$ of NP-LASPO $(0.10 \mathrm{U})$ and incubated at $70{ }^{\circ} \mathrm{C} .(-)$ before NP-LASPO addition; (-.-) 30 and (...) 60 min after NP-LASPO addition. Glycine, Rt 10.5 min, was used as internal standard. is not oxidized. The addition of exogenous, free FAD positively affect the activity of NP-LASPO: a 2-fold increase in the activity of the enzyme immobilized on the NPs was obtained in the presence of a large excess of exogenous cofactor in the HRPcoupled assay mixture, this indicating that half of StLASPO is immobilized in the apoprotein, inactive form.

To investigate the storage stability, the NP-LASPO system was stored in $5 \mathrm{mM}$ sodium pyrophosphate buffer $(\mathrm{pH} 8.5)$ at $25^{\circ} \mathrm{C}$ : $70 \%$ of the initial activity was maintained after 35 days.

The effect of $\mathrm{pH}$ on the catalytic activity of NP-LASPO was investigated in the 8.0 to 11.0 range, by following the disappearance of the L-aspartate peak by HPLC separation (Fig. 3).

Fig. 4, panel A left, displays the activity curves of the enzyme at different $\mathrm{pH}$ values. At $\mathrm{pH} 9,10$ and 11 the complete oxidation of $\mathrm{L}^{-}$ aspartate is observed in 3 hours, while at $\mathrm{pH} 8$ the reaction stops to approximately $90 \%$ of conversion. When compared to the free enzyme form, the immobilized enzyme shows a full stability at $\mathrm{pH}$ values 9-11 after $60 \mathrm{~min}$ of incubation, while for the free StLASPO the stability strongly decreases at $\mathrm{pH}>8$ (Fig. $4 \mathrm{~A}$, right). Similarly, earlier studies demonstrated that immobilized enzymes are frequently more stable than free enzymes in an alkaline environment. ${ }^{24,29}$

The effect of temperature on the catalytic activity of conjugated StLASPO was investigated in the $25-80{ }^{\circ} \mathrm{C}$ range (Fig. 4B). The NP-enzyme system shows a good activity in the range of 60$80^{\circ} \mathrm{C}$ : the fastest $\mathrm{L}$-aspartate oxidative deamination is apparent at $70{ }^{\circ} \mathrm{C}$. Only at $\leq 37{ }^{\circ} \mathrm{C}$ a partial conversion of the $50 \mathrm{mM} \mathrm{L}^{-}$ aspartate solution was obtained after $420 \mathrm{~min}$. Fig. $4 \mathrm{~B}$ right shows that the thermostability of NP-LASPO after $30 \mathrm{~min}$ of incubation parallel the behavior observed for the free enzyme.

The catalytic parameters of StLASPO immobilized on the $\mathrm{Fe}_{3}$ $\mathrm{O}_{4} \mathrm{NPs}$ were determined by a HRP-coupled spectrophotometric assay at $\mathrm{pH} 10.0$ at $25{ }^{\circ} \mathrm{C}$. The apparent $V_{\max }$ at air oxygensaturation for the NP-LASPO system is $0.11 \mu \mathrm{mol}$ per min 

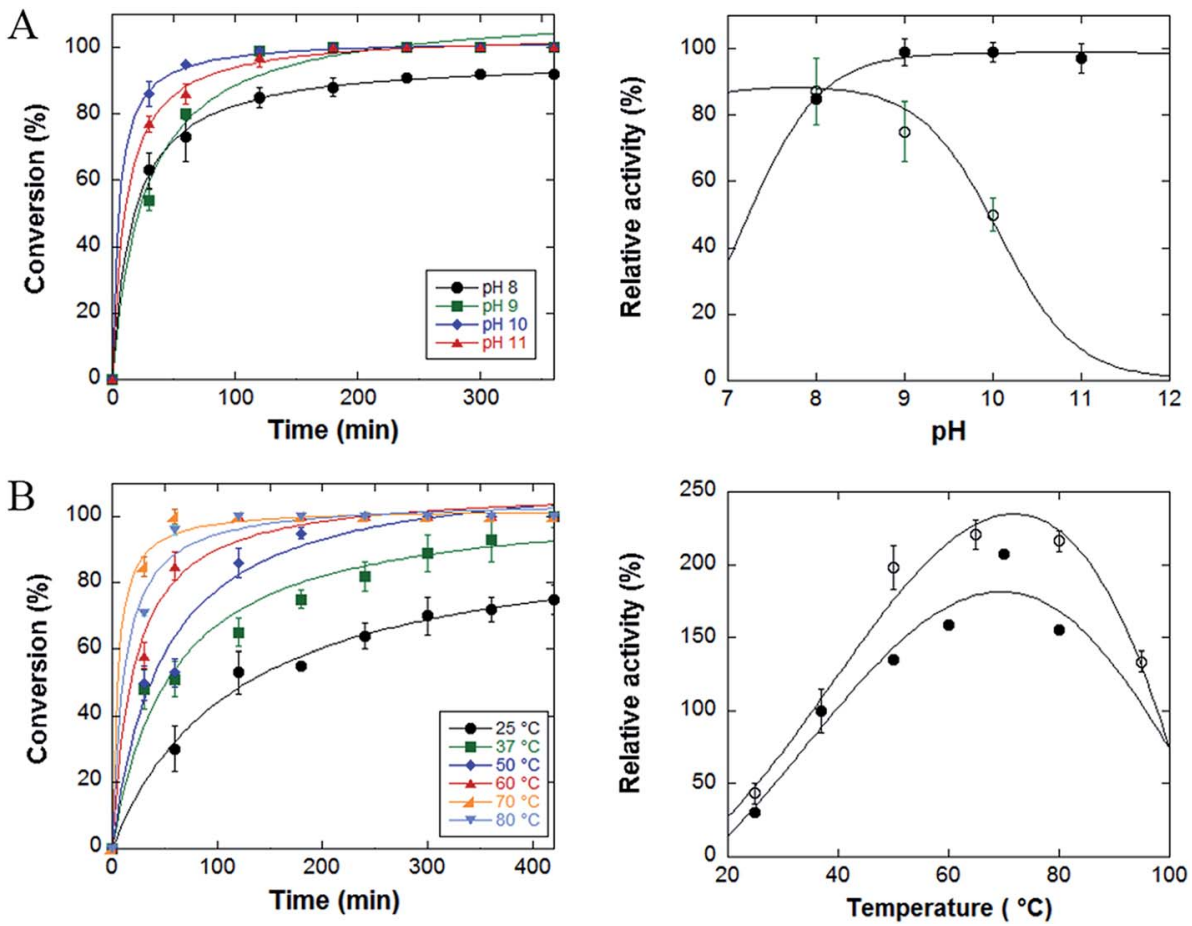

Fig. 4 (A) Left: effect of $\mathrm{pH}$ on the time course of oxidation of L-aspartate. Conditions: $50 \mu \mathrm{L}$ of $50 \mathrm{mM} \mathrm{L-aspartate,} 0.10 \mathrm{U}$ of NP-LASPO, $70{ }^{\circ} \mathrm{C}$. Right: comparison of residual activity after $60 \mathrm{~min}$ of incubation as function of pH for free StLASPO (open symbols) and NP-LASPO (filled symbols). Data are expressed as percentage of the activity values measured at the beginning of the reaction. (B) Left: effect of temperature on the time course of oxidative deamination of L-aspartate. Conditions: $50 \mu \mathrm{L}$ of $50 \mathrm{mM}$ L-aspartate at pH 10.0, $0.208 \mathrm{U}$ of NP-LASPO. Right: comparison of residual activity after 30 min of incubation as function of $\mathrm{pH}$ for free StLASPO (open symbols) and NP-LASPO (filled symbols). The value at $37^{\circ} \mathrm{C}$ was set as $100 \%$. The values are the average of at least three measurements; bars represent standard error.

per $\mathrm{mg}$ of protein and $K_{\mathrm{m}}$ for L-aspartate is $4.3 \mathrm{mM}$. The corresponding values for the free enzyme form are $0.98 \mu \mathrm{mol}$ per min per mg enzyme and $1.3 \mathrm{mM}$ at pH 8.0 and $37^{\circ} \mathrm{C} .{ }^{4}$ The higher $K_{\mathrm{m}}$ of NP-LASPO suggests a lower affinity for $\mathrm{L}$-aspartate by the immobilized enzyme so a higher substrate concentration is needed to achieve a given enzyme activity. Diffusional limitations and steric effects may contribute to the increased apparent $K_{\mathrm{m}}$ value due to a decrease in the accessibility of substrate to the enzyme active site. Similar effects are frequently reported for enzyme immobilized with EDC/NHS protocol, e.g., Tee and colleagues ${ }^{33}$ suggest that the high loading of the enzyme molecules using a zero-length crosslinker might restrict the access of the substrate to the active sites.

\section{Bioconversion by NP-LASPO}

The enzyme immobilization on magnetic NPs allows a simple recovery of the biocatalyst and its reuse, making this system interesting for industrial applications. To determine the number of reaction cycles that immobilized StLASPO can carry out, the same batch of enzyme was reused for subsequent cycles. Full oxidative deamination of $50 \mu \mathrm{L}$ of $50 \mathrm{mM}$ L-aspartate was obtained in 240 min using optimal operational conditions, i.e., at $\mathrm{pH} 10,50{ }^{\circ} \mathrm{C}$ and using $0.2 \mathrm{U}$ of the NP-enzyme system. Under these conditions, a full conversion was observed for three sequential cycles, while a longer reaction time was required for the following cycles (Fig. 5): after 420 min of reaction, $\leq 70 \%$ of the substrate was converted in the fifth and sixth cycle. Notably, under optimized conditions, the Relizyme-StLASPO fully converted $25 \mathrm{mM}$ L-aspartate for three sequential cycles of 4 hours

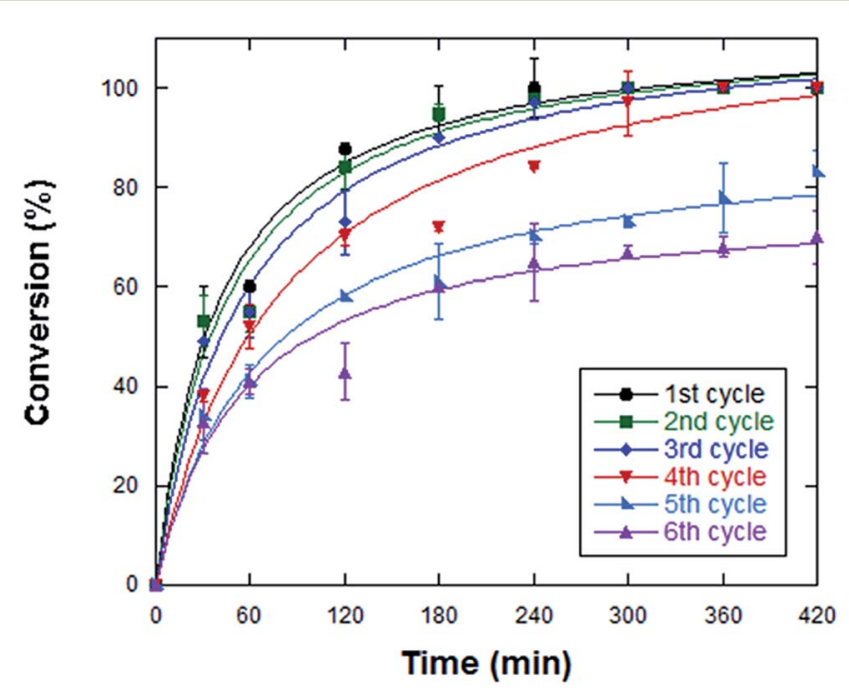

Fig. 5 Dependence of NP-LASPO activity at $50{ }^{\circ} \mathrm{C}$ and $\mathrm{pH} 10$ on recycling. Conditions: $50 \mu \mathrm{L}$ of $50 \mathrm{mM}$ L-aspartate, $0.20 \mathrm{U}$ of NPLASPO, $50{ }^{\circ} \mathrm{C}$ and $\mathrm{pH} 10$. The values are the average of at least three measurements; bars represent standard errors. 
onlyd, ${ }^{7}$ pointing to partial inactivation of the immobilized flavoenzyme. Taking into consideration the four cycles that resulted in full L-aspartate oxidation, $50 \mu$ moles of substrate were converted per unit of NP-LASPO. As compared to the free enzyme form, which fully converted $30 \mathrm{~mL}$ of $25 \mathrm{mM}$-aspartate in $24 \mathrm{~h}$ by using $9 \mathrm{U}$ of StLASPO ${ }^{4}$ corresponding to $3.5 \mu$ moles per $h$ per unit, the NP-LASPO converted $3.1 \mu$ mole per $h$ per unit at $\mathrm{pH} 10.0$ and $50{ }^{\circ} \mathrm{C}$. Indeed, the Relizyme-StLASPO - using 10 $\mathrm{mL}$ of $100 \mathrm{mM}$ D,L-Asp, at $\mathrm{pH} 10.0$ and $70{ }^{\circ} \mathrm{C}$ - converted 1 $\mu$ moles per $\mathrm{h}$ per unit (or $\sim 4.4 \mu$ moles per $\mathrm{h}$ per unit using 0.5 $\mathrm{mL}$ of $142 \mathrm{mM}$ D,L-Asp). ${ }^{7}$

\section{Conclusions}

In this work, the stereo-selective flavoenzyme L-aspartate oxidase from the thermophilic archaea Sulfolobus tokodaii has been covalently immobilized on $\mathrm{Fe}_{3} \mathrm{O}_{4}$ NPs using EDC and NHS as cross-linking agents. The optimal conditions for the enzyme immobilization were identified by investigating the interaction effect of different variables.

The NP-LASPO showed a better stability than the free enzyme at $\mathrm{pH} \geq 9.0$ and was reused five times reaching full $\mathrm{L}$-aspartate conversion, similarly to that previously obtained for the Relizyme-StLASPO preparation which employed a 2.5-fold higher amount of enzyme and longer times. ${ }^{7}$ L-Aspartate conversion by NP-LASPO yielded a productivity similar to that obtained using the free enzyme (that cannot be recycled) or the enzyme bound to the amino support Relizyme ${ }^{\mathrm{TM}}$ HA403/S R (3.1 vs. 1-4 $\mu \mathrm{mol}$ per $\mathrm{h}$ per unit of enzyme at $50 \mathrm{mM}$-aspartate concentration). These results indicate that the prepared NPs are favorable for immobilization of LASPO and the immobilized enzyme has promising industrial applications.

\section{Acknowledgements}

Ilaria Armenia and Riccardo Balzaretti are PhD students of the "Biotechnology, Biosciences and Surgical Technology" course at Università degli studi dell'Insubria. Chiara Allegretti is a $\mathrm{PhD}$ student of the Research Doctorate Program in Chemical Engineering and Industrial Chemistry at Politecnico di Milano. We thank the support from Consorzio Interuniversitario per le Biotecnologie.

\section{Notes and references}

1 G. Tedeschi, A. Negri, M. Mortarino, F. Ceciliani, T. Simonic, L. Faotto and S. Ronchi, Eur. J. Biochem., 1996, 239, 427-433.

2 P. Macheroux, O. Seth, C. Bollschweiler, M. Schwarz, M. Kurfürst, L. C. Au and S. Ghisla, Eur. J. Biochem., 2001, 268, 1679-1686.

3 H. Sakuraba, K. Yoneda, I. Asai, H. Tsuge, N. Katunuma and T. Ohshima, Biochim. Biophys. Acta, Proteins Proteomics, 2008, 1784, 563-571.

4 D. Bifulco, L. Pollegioni, D. Tessaro, S. Servi and G. Molla, Appl. Microbiol. Biotechnol., 2013, 97, 7285-7295.

5 L. Pollegioni, P. Motta and G. Molla, Appl. Microbiol. Biotechnol., 2013, 97, 9323-9341.
6 L. Pollegioni and G. Molla, Trends Biotechnol., 2011, 29, 276283.

7 P. D'Arrigo, C. Allegretti, A. Fiorati, L. Piubelli, E. Rosini, D. Tessaro, M. Valentino and L. Pollegioni, Catal. Sci. Technol., 2015, 5, 1106-1114.

8 A. H. Lu, E. L. Salabas and F. Schüth, Angew. Chem., Int. Ed., 2007, 46, 1222-1244.

9 A. Bava, R. Gornati, F. Cappellini, L. Caldinelli, L. Pollegioni and G. Bernardini, Nanomedicine, 2013, 8, 1797-1806.

10 R. Balzaretti, F. Meder, M. P. Monopoli, L. Boselli, I. Armenia, L. Pollegioni, G. Bernardini and R. Gornati, RSC Adv., 2017, 7, 1439-1442.

11 F. Cappellini, C. Recordati, M. De Maglie, L. Pollegioni, F. Rossi, M. Daturi, R. Gornati and G. Bernardini, Future Sci. OA, 2015, $1,4$.

12 A. G. Cattaneo, R. Gornati, E. Sabbioni, M. Chiriva-Internati, E. Cobos, M. R. Jenkins and G. Bernardini, J. Appl. Toxicol., 2010, 30, 730-744.

13 R. Gornati, E. Pedretti, F. Rossi, F. Cappellini, M. Zanella, I. Olivato, E. Sabbioni and G. Bernardini, J. Appl. Toxicol., 2016, 36, 385-393.

14 C. G. C. M. Netto, H. E. Toma and L. H. Andrade, J. Mol. Catal. B: Enzym., 2013, 85-86, 71-92.

15 H. Vaghari, H. Jafarizadeh-Malmiri, M. Mohammadlou, A. Berenjian, N. Anarjan, N. Jafari and S. Nasiri, Biotechnol. Lett., 2016, 38, 223-233.

16 A. Bava, F. Cappellini, E. Pedretti, F. Rossi, E. Caruso, E. Vismara, M. Chiriva-Internati, G. Bernardini and R. Gornati, BioMed Res. Int., 2013, 2013, 314091.

17 C. M. Harris, L. Pollegioni and S. Ghisla, Eur. J. Biochem., 2001, 268, 5504-5520.

18 Y. Mutaguchi and T. Ohshima, Biochemistry, 2014, 4, 2-5.

19 H. Jędrzejewska and R. Ostaszewski, J. Mol. Catal. B: Enzym., 2013, 90, 12-16.

20 G. T. Hermanson, Bioconjugate techniques, Academic Press, 3rd edn, 2013.

21 S. Sam, L. Touahir, J. Salvador Andresa, P. Allongue, J. N. Chazalviel, A. C. Gouget-Laemmel, C. H. De Villeneuve, A. Moraillon, F. Ozanam, N. Gabouze and S. Djebbar, Langmuir, 2010, 26, 809-814.

22 S. K. Vashist, Diagnostics, 2012, 2, 23-33.

23 L. S. Wong, F. Khan and J. Micklefield, Chem. Rev., 2009, 109, 4025-4053.

24 M. Jain, A. Mariya Sebatini, P. Radha, S. Kiruthika, C. Muthukumaran and K. Tamilarasan, J. Mol. Catal. B: Enzym., 2016, 128, 1-9.

25 F. Kazenwadel, H. Wagner, B. E. Rapp and M. Franzreb, Anal. Methods, 2015, 7, 10291-10298.

26 K. Turcheniuk, A. V. Tarasevych, V. P. Kukhar, R. Boukherroub and S. Szunerits, Nanoscale, 2013, 5, 10729-10752.

27 J. Xu, J. Sun, Y. Wang, J. Sheng, F. Wang and M. Sun, Molecules, 2014, 19, 11465-11486.

28 H. J. Park, J. T. McConnell, S. Boddohi, M. J. Kipper and P. A. Johnson, Colloids Surf., B, 2011, 83, 198-203.

29 C. Yen, Y. Chuang, C. Ko, L. O. Chen, S. Chen, C. Lin, Y. Chou and J. Shaw, Molecules, 2016, 21, 972. 
30 B. Sahoo, S. K. Sahu and P. Pramanik, J. Mol. Catal. B: Enzym., 2011, 69, 95-102.

31 S. L. Hosseinipour, M. S. Khiabani, H. Hamishehkar and R. Salehi, J. Nanopart. Res., 2015, $17(9), 382$.
32 R. A. Sperling and W. J. Parak, Philos. Trans. R. Soc., A, 2010, 368, 1333-1383.

33 B. L. Tee and G. Kaletunç, Biotechnol. Prog., 2009, 25, 436445. 